\title{
Copper(II)-catalyzed O-phenylation of alcohols with organobismuth(V) reagents
}

\author{
Naoto Sakurai, ${ }^{a}$ Kazuhiro Ikegai, ${ }^{a}$ and Teruaki Mukaiyamaa,b \\ ${ }^{a}$ Center for Basic Research, The Kitasato Institute, 6-15-5 (TCI) Toshima, Kita-ku, \\ Tokyo 114-0003 \\ ${ }^{b}$ Kitasato Institute for Life Sciences, Kitasato University, 5-9-1 Shirokane, Minato-ku, \\ Tokyo 108-8641 \\ E-mail: Mukaiyam@abeam.ocn.ne.jp
}

Dedicated to Professor Atta-ur-Rahman on the occasion of his 65th birthday

\begin{abstract}
A convenient method for the $\mathrm{Cu}(\mathrm{II})$-catalyzed O-phenylation of tertiary alcohols with organobismuth(V) compounds under mild conditions is described. Functionalized tertiary alcohols such as $\alpha$-hydroxy carbonyl compounds were phenylated by using either $\mathrm{Ph}_{3} \mathrm{Bi}(\mathrm{OAc})_{2}$ or tetraphenylbismuth compounds. In the cases of O-phenylation of simple tertiary alcohols, the use of tetraphenylbismuth fluoride $\left(\mathrm{Ph}_{4} \mathrm{BiF}\right)$ was particularly effective and gave various tertalkyl phenyl ethers in high yields. The synthesis of alkyl phenyl ethers from primary and secondary alcohols are also described.
\end{abstract}

Keywords: Organobismuth reagent, $O$-phenylation, tertiary alcohol, copper catalysis, ether synthesis

\section{Introduction}

Aryl ethers are quite useful compounds in organic synthesis, whose synthetic methods have therefore been studied by many groups. Transition metal-catalyzed $(\mathrm{Cu}$ or $\mathrm{Pd})$ coupling reactions between aryl halides and alcohols are often used in the synthesis of alkyl aryl ether. The Ullmann ether synthesis, ${ }^{1}$ for example, has now become a classical method for the Cu-mediated etherification. ${ }^{2}$ However, this method was not convenient since it needed harsh reaction conditions such as high temperatures, uses of strong bases and stoichiometric amounts of copper or copper salts, long reaction times and so on, besides yields of the product were moderate. Recently, Buchwald reported a coupling reaction between aryl halides and alcohols in the presence of a catalytic amount of $\mathrm{CuI}$ and 1,10-phenanthroline. ${ }^{3}$ Despite various aryl halides 
employed, there still needed refluxing conditions and long reaction times, and no tertiary alcohols were employed under the above conditions. On the other hand, Pd-catalyzed arylation was intensively studied by Hartwig ${ }^{4}$ and Buchwald ${ }^{5}$, and a coupling reaction of aryl halides and alcohols in the presence of bulky phosphine ligands was reported. Although tertiary alcohols employed in this reaction, there needed to use strongly basic alkoxides as nucleophiles. Furthermore, hardly any reactions of aryl halides that have strongly electron-donating substituents in the ortho or para positions took place. ${ }^{6}$ Then, a cross-coupling reaction of alcohols with organometalloid reagents such as organo-Bi and -B compounds was an alternative approach to the synthesis of alkyl aryl ethers. Recently, Batey reported that coupling reactions of alcohols with potassium aryltrifluoroborate salts proceeded in the presence of catalytic amounts of $\mathrm{Cu}(\mathrm{OAc})_{2}$ and 4-(dimethylamino)pyridine under essentially neutral conditions, ${ }^{7}$ which is a modified protocol of Chan-Evans's method for the arylation of phenols using aryl boronic acids. ${ }^{8}$ Although these $\mathrm{Cu}(\mathrm{II})$-catalyzed $O$-arylation reactions were carried out effectively with primary or secondary alcohols, a similar etherification of sterically-hindered secondary alcohols such as $(-)$-menthol and tertiary alcohols did not proceed at all.

It is also known that organobismuth(V) reagents transfer their aryl groups to aliphatic alcohols in the presence of copper catalysts. Through the intensive studies on Bi-mediated arylation of alcohols during these decades, ${ }^{9}$ Barton, ${ }^{10}$ Finet, ${ }^{11}$ and Dodonov ${ }^{12}$ introduced useful methods for $O$-phenylation by using organobismuth compounds (1. combination with $\mathrm{Ph}_{3} \mathrm{Bi}(\mathrm{OAc})_{2}$ and catalytic amounts of $\mathrm{Cu}(\mathrm{OAc})_{2}, 2 . \mathrm{Ph}_{3} \mathrm{Bi}$ and a stoichiometric amount of $\mathrm{Cu}(\mathrm{OAc})_{2}, 3 . \mathrm{Ph}_{4} \mathrm{BiOCOCF}_{3}$ in benzene or toluene under reflux.). Whereas the yields of primary and secondary alcohols were moderate, the yields of tertiary alcohols stayed low in these phenylation methods. Interestingly, it was reported that the reactivity of $\mathrm{Ph}_{4} \mathrm{BiOCOCF}_{3}$ and $\mathrm{Ph}_{3} \mathrm{Bi}(\mathrm{OAc})_{2}$ toward hydroxyl functions was greatly improved by the presence of a neighboring group such as hydroxyl, carbonyl, and sulfanyl. ${ }^{13}$ It was reported that the chelating effect was utilized in $O$-arylation of hydroxyl groups of biologically-active natural products in Merck medicinal chemistry group. ${ }^{14}$

Very recently, $O$-phenylation of tertiary alcohols by using organobismuth(V) reagents was also reported from our laboratory. ${ }^{15}$ Since effective $\mathrm{C}($ aryl $)-\mathrm{O}$ bond formation of simple tertiary alcohols under mild conditions has not yet been developed, $O$-phenylation of simple tertiary alcohols using organobismuth(V) compounds under mild conditions was examined. Further, a reactivity difference between a functionalized alcohol and a simple alcohol was discussed.

\section{Result and Discussion}

The reactivity of the organobismuth(V) reagents was initially examined by using ethyl 2hydroxy-2-methylpropionate (1a) as a model for a functionalized alcohol because of its chelating effect and 2-methyl-4-phenyl-butan-2-ol (1b) as a model for a simple alcohol. $O$-Phenylation of the alcohols was examined by using Bi reagents (1.6 equiv.) in the presence of catalytic amounts 
of copper salts and $\mathrm{N}, \mathrm{N}$-dicyclohexylmethylamine $\left(\mathrm{Cy}_{2} \mathrm{NMe}\right)$ in $\mathrm{CH}_{2} \mathrm{Cl}_{2}$ at room temperature. The reactions were carried out without excluding moisture (Scheme 1), and the results are summarized in Table 1.

functionalized alcohol alcohol

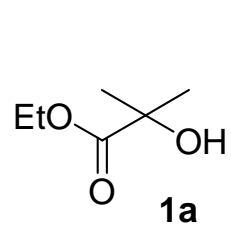

$\mathrm{Bi}(\mathrm{V})$ reagent $\mathrm{Cu}(\mathrm{OAc})_{2}$ (catalytic) $\mathrm{Cy}_{2} \mathrm{NMe}$ (2 equiv.) $\mathrm{CH}_{2} \mathrm{Cl}_{2}$ rt $3 \mathrm{~h}$
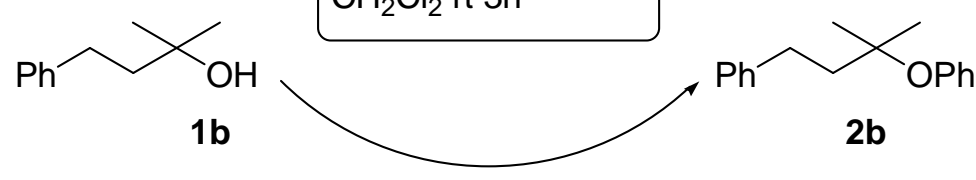

Scheme 1. $O$-phenylation of tertiary alcohol with organobismuth(V) compounds.

Concerning triphenyl bismuth reagents, functionalized alcohol 1a was efficiently phenylated in $89 \%$ yield when $\mathrm{Ph}_{3} \mathrm{Bi}(\mathrm{OAc})_{2}$ was used (Entry 1). This phenylation proceeded efficiently even when the $\mathrm{Cu}(\mathrm{OAc})_{2}$ catalyst was reduced to $1 \mathrm{~mol} \%$ (Entry 2). However, simple alcohol $\mathbf{1 b}$ was not phenylated at all by using $\mathrm{Ph}_{3} \mathrm{Bi}(\mathrm{OAc})_{2}$ when the amount of $\mathrm{Cu}(\mathrm{OAc})_{2}$ catalyst was increased even to $15 \mathrm{~mol} \%$ and phenyl acetate was obtained as a major product under these conditions (Entries 15 and 16). Other triphenyl bismuth derivatives were less effective (Entries 3-8). On the other hand, most tetraphenyl bismuth reagents afforded 2a in over $85 \%$ yield, yet the $\mathrm{Ph}_{4} \mathrm{BiOTs}$ did not afford 2a (Entries 9-13). Under these conditions, pentaphenylbisumuth gave mainly biphenyl (Entry 14). In the case of $\mathbf{1 b}$, the expected phenyl ether was not formed when tetraphenylbismuth complexes such as $\left[\mathrm{Ph}_{4} \mathrm{Bi}^{+}\right]\left[\mathrm{BF}_{4}^{-}\right]$or $\left[\mathrm{Ph}_{4} \mathrm{Bi}^{+}\right]\left[\mathrm{OTf}^{-}\right]$were employed (Entries 18 and 19). Instead, the desired phenyl ether was obtained in $6 \%$ or $54 \%$ yields, respectively, when the reaction was carried out in the presence of $\mathrm{Ph}_{4} \mathrm{BiOCOCF}_{3}$ or $\mathrm{Ph}_{4} \mathrm{BiF}$ (Entries 17 and 20) though the reaction itself was sluggish by using $5 \mathrm{~mol} \%$ of $\mathrm{Cu}(\mathrm{OAc})_{2}$ (Entry 21). Although $O$-phenylation of both functionalized and simple alcohols took place efficiently when $\mathrm{Ph}_{4} \mathrm{BiF}$ was used, other pentavalent bismuth(V) derivatives showed remarkable differences in their reactivity. 
Table 1. Effect of organobismuth(V) reagents

\begin{tabular}{|c|c|c|c|c|c|}
\hline Alcohol & Entry & Bi reagent & $\mathrm{Cu}(\mathrm{OAc})_{2}(\mathrm{~mol} \%)$ & Isolated yield (\%) & \\
\hline \multirow{14}{*}{$\prod_{\mathrm{O}}>_{\mathbf{1 a}}$} & 1 & $\mathrm{Ph}_{3} \mathrm{Bi}(\mathrm{OAc})_{2}$ & 5 & 89 & \multirow{14}{*}{$\mathrm{EtO}_{\mathrm{O}}$} \\
\hline & 2 & $\mathrm{Ph}_{3} \mathrm{Bi}(\mathrm{OAc})_{2}$ & 1 & 79 & \\
\hline & 3 & $\mathrm{Ph}_{3} \mathrm{Bi}\left(\mathrm{OCOCF}_{3}\right)_{2}$ & 5 & 5 & \\
\hline & 4 & $\mathrm{Ph}_{3} \mathrm{Bi}(\mathrm{OTs})_{2}$ & 5 & ND & \\
\hline & 5 & $\mathrm{Ph}_{3} \mathrm{Bi}(\mathrm{OMs})_{2}$ & 5 & ND & \\
\hline & 6 & $\mathrm{Ph}_{3} \mathrm{BiF}_{2}$ & 5 & EtO & \\
\hline & 7 & $\mathrm{Ph}_{3} \mathrm{BiCO}_{3}$ & 5 & Liv & \\
\hline & 8 & $\mathrm{Ph}_{3} \mathrm{BiCl}_{2}$ & 5 & 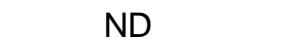 & \\
\hline & 9 & $\mathrm{Ph}_{4} \mathrm{BiOCOCF}_{3}$ & 5 & 85 & \\
\hline & 10 & $\mathrm{Ph}_{4} \mathrm{BiOTs}$ & 5 & ND & \\
\hline & 11 & {$\left[\mathrm{Ph}_{4} \mathrm{Bi}^{+}\right]\left[\mathrm{OTf}^{-}\right]$} & 5 & 86 & \\
\hline & 12 & {$\left[\mathrm{Ph}_{4} \mathrm{Bi}^{+}\right]\left[\mathrm{BF}_{4}^{-}\right]$} & 5 & 95 & \\
\hline & 13 & $\mathrm{Ph}_{4} \mathrm{BiF}$ & 5 & 93 & \\
\hline & 14 & $\mathrm{Ph}_{5} \mathrm{Bi}$ & 5 & ND & \\
\hline \multirow{7}{*}{$1 \mathrm{k}$} & 15 & $\mathrm{Ph}_{3} \mathrm{Bi}(\mathrm{OAc})_{2}$ & 5 & ND & \multirow{7}{*}{${ }_{2 b}$} \\
\hline & 16 & $\mathrm{Ph}_{3} \mathrm{Bi}(\mathrm{OAc})_{2}$ & 15 & ND & \\
\hline & 17 & $\mathrm{Ph}_{4} \mathrm{BiOCOCF}_{3}$ & 15 & $\widehat{\mathrm{Ph}}$ & \\
\hline & 18 & {$\left[\mathrm{Ph}_{4} \mathrm{Bi}^{+}\right]\left[\mathrm{OTf}^{-}\right]$} & 15 & $\mathrm{ND} \mathrm{Ph}^{-}$ & \\
\hline & 19 & {$\left[\mathrm{Ph}_{4} \mathrm{Bi}^{+}\right]\left[\mathrm{BF}_{4}^{-}\right]$} & 15 & 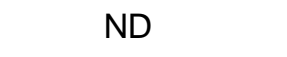 & \\
\hline & 20 & $\mathrm{Ph}_{4} \mathrm{BiF}$ & 15 & 54 & \\
\hline & 21 & $\mathrm{Ph}_{4} \mathrm{BiF}$ & 5 & 3 & \\
\hline
\end{tabular}

The effects of copper salts and solvents were examined next and the corresponding results are summarized in Table 2. Concerning 1a, the reaction proceeded smoothly in methyl ethyl ketone (MEK), THF, $\mathrm{CH}_{3} \mathrm{CN}$ and toluene while it proceeded sluggishly when DMF was used (Entries 1-5). With respect to copper salts, $\mathrm{Cu}(\mathrm{OAc})_{2}$ was the most useful for the promotion of this reaction. On the other hand, $\mathrm{CuOAc}$ and other $\mathrm{Cu}$ (II) salts $\left(\mathrm{CuF}_{2}, \mathrm{Cu}\left(\mathrm{OCOCF}_{3}\right)_{2} \mathrm{xH}_{2} \mathrm{O}\right.$ and $\mathrm{Cu}(\mathrm{OTf})_{2}$ ) were less effective (Entries 6-9) and no reactions proceeded in the absence of a copper salt (Entry 10). In the case of $\mathbf{1 b}$, it was shown that the use of a non-polar solvent such as toluene gave the best result and $\mathbf{2 b}$ was obtained in $84 \%$ yield (Entry 15) whereas the use of polar solvents such as MEK, THF, $\mathrm{CH}_{3} \mathrm{CN}$, DMF resulted in giving poor yields (Entries 11-14). When the amounts of $\mathrm{Ph}_{4} \mathrm{BiF}$ and $\mathrm{Cu}(\mathrm{OAc})_{2}$ increased to 2 equiv. and $20 \mathrm{~mol} \%$, respectively, $2 \mathbf{b}$ was afforded in a quantitative yield (Entry 16). The effects of copper salts in toluene were then examined and $\mathrm{Cu}\left(\mathrm{OCOCF}_{3}\right)_{2} \times \mathrm{xH}_{2} \mathrm{O}$ was found to give $\mathbf{2 b}$ in $63 \%$ yield (Entry 18) but $\mathrm{CuOAc}$, $\mathrm{Cu}(\mathrm{OTf})_{2}$ and $\mathrm{CuF}_{2}$ were hardly effective (Entries 17, 19 and 20). Thus it was proved best to use of $\mathrm{Ph}_{4} \mathrm{BiF}$ (2 equiv.), $\mathrm{Cu}(\mathrm{OAc})_{2}\left(20 \mathrm{~mol} \%\right.$ ) and $\mathrm{Cy}_{2} \mathrm{NMe}$ (2 equiv.) in toluene for the phenylation of simple alcohol. Although $O$-phenylation of both functionalized and simple alcohols took place efficiently when $\mathrm{Cu}(\mathrm{OAc})_{2}$ was used, remarkable reactivity differences were observed in the cases of using other copper salts. 
Table 2. Effect of copper salts and solvents

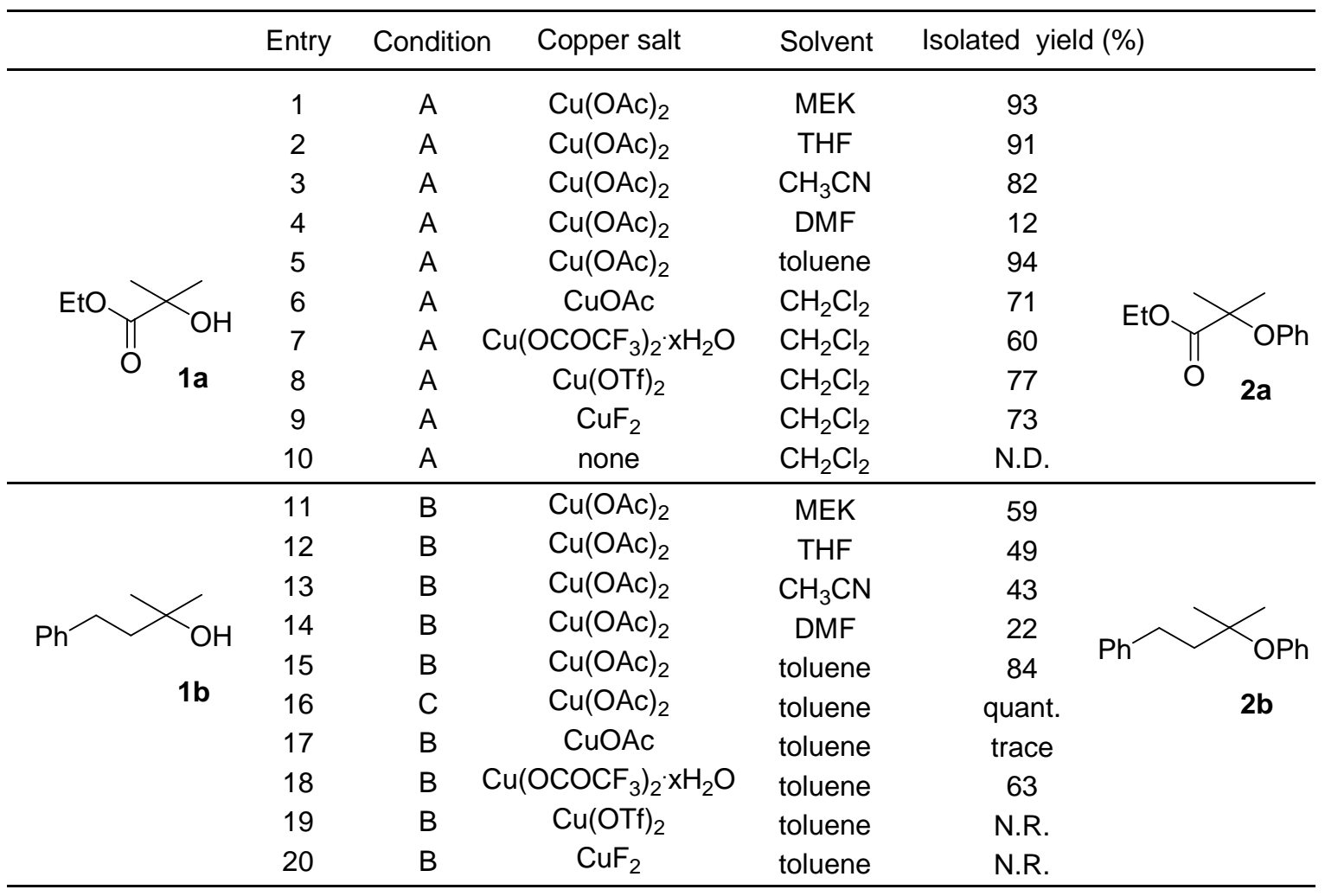

condition $\mathrm{A}:\left[\mathrm{Ph}_{4} \mathrm{Bi}^{+}\right]\left[\mathrm{BF}_{4}{ }^{-}\right]$(1.6 equiv.) and $\mathrm{Cu}$ salts $(5 \mathrm{~mol} \%)$ were used.

condition $\mathrm{B}: \mathrm{Ph}_{4} \mathrm{BiF}$ (1.6 equiv.) and $\mathrm{Cu}$ salts $(15 \mathrm{~mol} \%)$ were used.

condition $\mathrm{C}: \mathrm{Ph}_{4} \mathrm{BiF}$ (2.0 equiv.) and $\mathrm{Cu}$ salts $(20 \mathrm{~mol} \%)$ were used.

ND: Not Detected

The $O$-phenylation reactions of simple tertiary alcohols (1c-1k) with $\mathrm{Ph}_{4} \mathrm{BiF}$ under the above optimized conditions are shown in Table 3. The reactions of tertiary alcohols by using 2.0 equiv. of $\mathrm{Ph}_{4} \mathrm{BiF}$ such as $t$-butanol (1c), 2-phenylpropan-2-ol (1d), 2-(4-bromophenyl)propan-2-ol (1e), 1-methylcyclohexanol (1f) and adamanthan-1-ol (1g) gave the corresponding phenyl ethers $(\mathbf{2 c}-\mathbf{2 g})$ in more than $86 \%$ yields. It is noted that the reaction of $1 \mathbf{e}$ gave the phenyl ether $2 \mathbf{e}$ in 86 $\%$ yield without affecting the $p$-bromophenyl moiety that was not used for the previously reported $\mathrm{Pd}$ - or $\mathrm{Cu}$-catalyzed $\mathrm{O}$-arylation. Additionally, secondary alcohols such as 4phenylbutan-2-ol (1h), cyclohexanol (1i), (-)-menthol (1j) and a primary alcohol such as 4phenylbutan-1-ol (1k) were phenylated efficiently to give the corresponding phenyl ethers in excellent yields without accompanying ketones or aldehydes formed by oxidation of alcohols with organobismuth(V) species. 
Table 3. Phenylation of simple alcohols

Entry

${ }^{\text {a }} \mathrm{Ph}_{4} \mathrm{BiF}$ (2 equiv.), $\mathrm{Cu}(\mathrm{OAc})_{2}\left(20 \mathrm{~mol} \%\right.$ ), and $\mathrm{Cy}_{2} \mathrm{NMe}(2$ equiv.) were used.

${ }^{\mathrm{b}} \mathrm{Ph}_{4} \mathrm{BiF}$ (1.5 equiv.), $\mathrm{Cu}(\mathrm{OAc})_{2}\left(15 \mathrm{~mol} \%\right.$ ), and $\mathrm{Cy}_{2} \mathrm{NMe}$ (2 equiv.) were used.

In conclusion, it is noted that a convenient method for the $O$-phenylation of simple tertiary alcohols by using a combination of $\mathrm{Ph}_{4} \mathrm{BiF}$ and catalytic amounts of $\mathrm{Cu}(\mathrm{OAc})_{2}$ under mild conditions was established. This method can be applied to the phenylation of various alcohols including primary and secondary alcohols. Further, remarkable reactivity differences were observed between the functionalized alcohol 1a and the simple alcohol $\mathbf{1 b}$ under the same phenylation conditions: that is, the alcohol 1a was effectively phenylated by the use of 
$\mathrm{Ph}_{3} \mathrm{Bi}(\mathrm{OAc})_{2},\left[\mathrm{Ph}_{4} \mathrm{Bi}^{+}\right]\left[\mathrm{BF}_{4}^{-}\right],\left[\mathrm{Ph}_{4} \mathrm{Bi}^{+}\right][\mathrm{OTf}], \mathrm{Ph}_{4} \mathrm{BiOCOCF}_{3}$, and $\mathrm{Ph}_{4} \mathrm{BiF}$. On the other hand, the simple alcohol $\mathbf{1 b}$ was effectively phenylated only when $\mathrm{Ph}_{4} \mathrm{BiF}$ was used as a phenyl donor. Thus, $\mathrm{Ph}_{4} \mathrm{BiF}$ can be the reagent of choice for the formation of $\mathrm{C}($ aryl $)-\mathrm{O}$ bond under mild conditions.

\section{Experimental Section}

General Procedures. Melting points were measured on a micro melting point apparatus (Yanaco MP-S3) and remain uncorrected. IR spectra were recorded on a Shimadzu IR-440 spectrophotometer ( $\mathrm{KBr}$ or neat) or a Thermo Electron Nicolet Avatar 370 spectrometer (ATR). ${ }^{1} \mathrm{H}$ NMR spectra were recorded on a JEOL JNM-EX270 (270 MHz) spectrometer. Chemical shifts $\left(\delta_{\mathrm{H}}\right)$ in $\mathrm{CDCl}_{3}$ are reported in parts per million (ppm) relative to tetramethylsilane (TMS). Splitting patterns are designated as s, singlet; d, doublet; t, triplet; q, quartet; quin, quintet; $\mathrm{m}$, multiplet; br, broad. ${ }^{13} \mathrm{C}$ NMR spectra were recorded on a JEOL JNM-EX270 (68 MHz) spectrometer with complete proton decoupling. Chemical shifts $\left(\delta_{\mathrm{C}}\right)$ in $\mathrm{CDCl}_{3}$ are reported in ppm relative to TMS using the solvent resonance $\left(\mathrm{CDCl}_{3}: \delta_{\mathrm{C}} 77.0 \mathrm{ppm}\right)$ as an internal standard. HRMS spectra were recorded on a JEOL JMS-700V (EI positive) and Agilent 6890 series GC system. Analytical TLC was performed on Merck TLC plates coated with silica gel $\left(60 \mathrm{~F}_{254}, 0.25\right.$ $\mathrm{mm})$. Silica gel column chromatography was performed on Merck Silica gel 60 (0.063-0.200 $\mathrm{mm}$ ). Preparative TLC was carried out on glass plates coated with silica gel (Wakogel B-5F). Anhydrous THF, DMF and $\mathrm{CH}_{3} \mathrm{CN}$ were purchased from Kanto Chemical Co., Inc.. Other solvents were distilled after dehydrated by using appropriate drying agents. Alcohols and $\mathrm{Cy}_{2} \mathrm{NMe}$ were purchased from Tokyo Kasei Kogyo. Copper(II) acetate was purchased from Kanto Chemical Co., Inc.. All reagents were purchased from Tokyo Kasei Kogyo, Kanto Chemical Co., Inc., Wako Pure Chemical Industry or Aldrich, and commercially-available reagents were used without purification.

\section{Preparation of organobismuth(V) reagents}

All organobismuth(V) derivatives such as triphenylbismuth diacetate $\left(\mathrm{Ph}_{3} \mathrm{Bi}(\mathrm{OAc})_{2}\right){ }^{16}$ triphenylbismuth bis(trifluoroacetate) $\quad\left(\mathrm{Ph}_{3} \mathrm{Bi}\left(\mathrm{OCOCF}_{3}\right)_{2}\right){ }^{16,17}$ triphenylbismuth di- $p$ toluenesulfonate $\left(\mathrm{Ph}_{3} \mathrm{Bi}(\mathrm{OTs})_{2}\right),{ }^{17}$ triphenylbismuth dimesylate $\left(\mathrm{Ph}_{3} \mathrm{Bi}(\mathrm{OMs})_{2}\right){ }^{16,17}$ triphenylbismuth difluoride $\left(\mathrm{Ph}_{3} \mathrm{BiF}_{2}\right),{ }^{18}$ triphenylbismuth carbonate $\left(\mathrm{Ph}_{3} \mathrm{BiCO}_{3}\right){ }^{17}$ triphenylbismuth dichloride $\left(\mathrm{Ph}_{3} \mathrm{BiCl}_{2}\right),{ }^{18}$ tetraphenylbismuth trifluoroacetate $\left(\mathrm{Ph}_{4} \mathrm{BiOCOCF} 3\right),{ }^{19}$ tetraphenylbismuth toluene- $p$-sulfonate $\quad\left(\mathrm{Ph}_{4} \mathrm{BiOTs}\right),{ }^{19} \quad$ tetraphenylbismuthonium tetrafluoroborate $\left(\left[\mathrm{Ph}_{4} \mathrm{Bi}^{+}\right]\left[\mathrm{BF}_{4}{ }^{-}\right],{ }^{20}\right.$ tetraphenylbismuthonium trifluoromethansulfonate $\left(\left[\mathrm{Ph}_{4} \mathrm{Bi}^{+}\right]\left[\mathrm{OTf}^{-}\right]\right){ }^{17}$ tetraphenylbismuth fluoride $\left(\mathrm{Ph}_{4} \mathrm{BiF}\right)^{21}$ and pentaphenylbismuth $\left(\mathrm{Ph}_{5} \mathrm{Bi}\right){ }^{22}$ were prepared from triphenylbismuthane $\left(\mathrm{Ph}_{3} \mathrm{Bi}\right)$ according to literature methods. ${ }^{23}$

Typical procedure for the $O$-phenylation of functionalized tertiary alcohol, ethyl 2hydroxy-2-methylpropionate (1a). To a solution of the alcohol 1a (39.6 $\mathrm{mg}, 0.30 \mathrm{mmol})$ and 
$\mathrm{Cu}(\mathrm{OAc})_{2}(2.7 \mathrm{mg}, 0.015 \mathrm{mmol})$ in anhydrous $\mathrm{CH}_{2} \mathrm{Cl}_{2}(1.5 \mathrm{~mL})$ was added $\mathrm{Cy}_{2} \mathrm{NMe}(0.127 \mathrm{~mL}$, $0.60 \mathrm{mmol})$ and the mixture was stirred at $\mathrm{rt}$ for $10 \mathrm{~min}$. Tetraphenylbisumuth(V) bismuth trifluoroacetate $\left(\left(\mathrm{Ph}_{4} \mathrm{BiOCOCF}_{3}\right) 303 \mathrm{mg}, 0.48 \mathrm{mmol}\right)$ was then added and the resulted solution was allowed to react at $\mathrm{rt}$ for $3 \mathrm{~h}$ under air without excluding moisture. The reaction was quenched by the addition of $5 \%$ aq $\mathrm{NH}_{3}$. The mixture was extracted with $\mathrm{CH}_{2} \mathrm{Cl}_{2}$ (3 times), and the combined organic layer was washed with brine and dried over $\mathrm{Na}_{2} \mathrm{SO}_{4}$. After concentration in vacuo, the residue was purified by preparative TLC on silica gel (hexane/AcOEt $=4 / 1$ ) to afford the desired phenyl ether 2a $(53.0 \mathrm{mg}, 0.25 \mathrm{mmol})$ in $85 \%$ yield.

Typical procedure for the $O$-phenylation of simple tertiary alcohol, 2-methyl-4phenylbutan-2-ol (1b). To a solution of the alcohol $\mathbf{1 b}(49.3 \mathrm{mg}, 0.3 \mathrm{mmol})$ and $\mathrm{Cy}_{2} \mathrm{NMe}(0.127$ $\mathrm{mL}, 0.6 \mathrm{mmol})$ in toluene $(1.5 \mathrm{~mL})$ was added $\mathrm{Cu}(\mathrm{OAc})_{2}(10.9 \mathrm{mg}, 20 \mathrm{~mol} \%)$ and the mixture was stirred at room temperature for $20 \mathrm{~min}$. Then, $\mathrm{Ph}_{4} \mathrm{BiF}(321.8 \mathrm{mg}, 0.6 \mathrm{mmol}$ ) was added and the resulted solution was kept stirring at $\mathrm{rt}$ for $1 \mathrm{~h}$. The reaction was carried out under air without excluding moisture. The reaction mixture was quenched with $5 \%$ aq. $\mathrm{NH}_{3}$ and the resulted mixture was extracted with $\mathrm{CH}_{2} \mathrm{Cl}_{2}$ (3 times), and the combined organic layer was washed with brine and dried over $\mathrm{Na}_{2} \mathrm{SO}_{4}$. After concentration in vacuo, the residue was purified by preparative TLC on silica gel (hexane/ $\left.\mathrm{CH}_{2} \mathrm{Cl}_{2}=1 / 1\right)$ to afford the desired phenyl ether $2 \mathbf{b}(72.8$ $\mathrm{mg}, 0.3 \mathrm{mmol})$ quantatively.

If a phenyl ether was not purified completely by using preparative TLC owing to difficulty of separation from $\mathrm{Ph}_{3} \mathrm{Bi}$ generated by the above reaction, triphenylbismuthane contained in the residue should be decomposed selectively before the second purification by preparative TLC. In the case of $2 \mathbf{e}$, ca. $40 \mathrm{uL}$ of $\mathrm{SO}_{2} \mathrm{Cl}_{2}$ was added dropwise to a $\mathrm{CH}_{2} \mathrm{Cl}_{2}$ solution of $\mathrm{Ph}_{3} \mathrm{Bi}$ and $2 \mathbf{e}$ at 0 until residual $\mathrm{Ph}_{3} \mathrm{Bi}$ disappeared, and then, $2 \mathbf{e}$ was purified again by preparative TLC. In the case of $2 \mathbf{i}$, ca. $120 \mathrm{uL}$ of trifluoroacetic acid was added dropwise to a $\mathrm{CH}_{2} \mathrm{Cl}_{2}$ solution of $\mathrm{Ph}_{3} \mathrm{Bi}$ and $2 \mathbf{i}$ until $\mathrm{Ph}_{3} \mathrm{Bi}$ disappeared, and then, insoluble white precipitate was filtered off, and $2 \mathbf{i}$ was purified again by preparative TLC.

2-(4-Bromophenyl)propan-2-ol (1e). ${ }^{24} \mathrm{~A}$ solution of methylmagnesium bromide $(1 \mathrm{~mol} / 1 \mathrm{in}$ THF, $2.4 \mathrm{~mL}, 2.4 \mathrm{mmol}$ ) was added at 0 to a solution of 4-bromo acetophenone (400 $\mathrm{mg}, 2$ $\mathrm{mmol})$ in $\mathrm{Et}_{2} \mathrm{O}(4 \mathrm{~mL})$. The resulting mixture was stirred at $\mathrm{rt}$ for $10 \mathrm{~h}$. The reaction mixture was quenched with sat aq. $\mathrm{NH}_{4} \mathrm{Cl}$ and the resulted mixture was extracted with $\mathrm{Et}_{2} \mathrm{O}$ (3 times), and the combined organic layer was washed with brine and dried over $\mathrm{MgSO}_{4}$ and concentrated under vacuo. The crude product was purified by column chromatography (silica gel, hexane/AcOEt = 5/1) to afford 1e (264 mg, $61 \%$ ) as a pale yellow oil.: IR (ATR, $\left.\mathrm{cm}^{-1}\right)$ 3372, 2975, 1483, 1395, 1364, 1167, 1093, 1008, 954, 859, 822, 731, 718; ${ }^{1} \mathrm{H}$ NMR $\left(270 \mathrm{MHz}, \mathrm{CDCl}_{3}\right) \delta=7.45(\mathrm{~d}, J=$ $8.6 \mathrm{~Hz}, 2 \mathrm{H}), 7.36(\mathrm{~d}, 8.9 \mathrm{~Hz}, 2 \mathrm{H}), 1.57(\mathrm{~s}, 6 \mathrm{H}) ;{ }^{13} \mathrm{C} \mathrm{NMR}\left(68 \mathrm{MHz}, \mathrm{CDCl}_{3}\right) \delta=148.0,131.1$, 126.2, 120.4, 72.2, 31.7 .

Ethyl 2-methyl-2-phenoxypropionate (2a). ${ }^{15 \mathrm{a}}$ Colorless oil; IR (ATR, $\mathrm{cm}^{-1}$ ) 1731, 1174, 1135, 751; ${ }^{1} \mathrm{H}$ NMR $\left(270 \mathrm{MHz}, \mathrm{CDCl}_{3}\right) \delta=7.28-7.18(\mathrm{~m}, 2 \mathrm{H}), 7.02-6.93(\mathrm{~m}, 1 \mathrm{H}), 6.88-6.80(\mathrm{~m}, 2 \mathrm{H})$, $4.23(\mathrm{q}, J=7.1 \mathrm{~Hz}, 2 \mathrm{H}), 1.59(\mathrm{~s}, 6 \mathrm{H}), 1.24(\mathrm{t}, J=7.1 \mathrm{~Hz}, 3 \mathrm{H}) ;{ }^{13} \mathrm{C} \mathrm{NMR}\left(68 \mathrm{MHz}, \mathrm{CDCl}_{3}\right) \delta=$ 174.1, 155.2, 129.0, 121.9, 118.9, 78.9, 61.4, 25.4, 14.1. 
1,1-Dimethyl-3-phenylpropyl phenyl ether (2b). Colorless oil; IR (ATR, $\mathrm{cm}^{-1}$ ) 2977, 1592, 1487, 1229, 1197, 1160, 887, 748, 695; ${ }^{1} \mathrm{H}$ NMR $\left(270 \mathrm{MHz}, \mathrm{CDCl}_{3}\right) \delta=7.31-7.15(\mathrm{~m}, 7 \mathrm{H})$, 7.09-6.99 (m, 3H), 2.86-2.80 (m, 2H), 2.00-1.93 (m, 2H), $1.35(\mathrm{~s}, 6 \mathrm{H}) ;{ }^{13} \mathrm{C}$ NMR $(68 \mathrm{MHz}$, $\left.\mathrm{CDCl}_{3}\right) \delta=155.3,142.4,128.8,128.3,128.3,125.6,123.8,123.1,80.0,44.2,30.7,26.8$; Anal. Calcd for $\mathrm{C}_{17} \mathrm{H}_{20} \mathrm{O}: \mathrm{C}, 84.95 ; \mathrm{H}, 8.39$. Found: $\mathrm{C}, 85.04 ; \mathrm{H}, 8.19$.

tert-Butyl phenyl ether (2c). ${ }^{6 \mathrm{~b}}$ Colorless oil; IR $\left(\mathrm{ATR}, \mathrm{cm}^{-1}\right)$ 2977, 1593, 1487, 1365, 1233, 1159, 925, 913, 887, 779, 695; ${ }^{1} \mathrm{H}$ NMR $\left(270 \mathrm{MHz}, \mathrm{CDCl}_{3}\right) \delta=7.29-7.23(\mathrm{~m}, 2 \mathrm{H}), 7.10-7.04$ $(\mathrm{m}, 1 \mathrm{H}), 7.01-6.97(\mathrm{~m}, 2 \mathrm{H}), 1.35(\mathrm{~s}, 9 \mathrm{H}) ;{ }^{13} \mathrm{C} \mathrm{NMR}\left(68 \mathrm{MHz}, \mathrm{CDCl}_{3}\right) \delta=155.3,128.7,124.1$, 123.2, 78.3, 29.0 .

1-Methyl-1-phenylethyl phenyl ether (2d). ${ }^{25}$ Colorless oil; IR (ATR, $\mathrm{cm}^{-1}$ ) 2982, 1597, 1489, $1228,1144,753,695 ;{ }^{1} \mathrm{H}$ NMR $\left(270 \mathrm{MHz}, \mathrm{CDCl}_{3}\right) \delta=7.50-7.46(\mathrm{~m}, 2 \mathrm{H}), 7.38-7.25(\mathrm{~m}, 3 \mathrm{H})$, 7.13-7.07 (m, 2H), 6.90-6.84 (m, 1H), 6.68-6.64 (m, 2H), $1.70(\mathrm{~s}, 6 \mathrm{H}) ;{ }^{13} \mathrm{C}$ NMR (68 MHz, $\left.\mathrm{CDCl}_{3}\right) \delta=155.9,146.6,128.7,128.3,126.9,125.2,121.2,120.2,80.1,29.5$; Anal. Calcd for $\mathrm{C}_{15} \mathrm{H}_{20} \mathrm{O}: \mathrm{C}, 84.87 ; \mathrm{H}, 7.60$. Found: C, 84.87; H, 7.74.

1-(4-Bromophenyl)-1-methylethyl phenyl ether (2e). Colorless oil; IR (ATR, $\mathrm{cm}^{-1}$ ) 2980, 1593, 1486, 1226, 1145, $10931008,822,753,693 ;{ }^{1} \mathrm{H}$ NMR $\left(270 \mathrm{MHz}, \mathrm{CDCl}_{3}\right) \delta=7.47(\mathrm{~d}, J=$ $8.9 \mathrm{~Hz}, 2 \mathrm{H}), 7.35(\mathrm{~d}, 8.9 \mathrm{~Hz}, 2 \mathrm{H}), 7.15-7.09(\mathrm{~m}, 2 \mathrm{H}), 6.92-6.87(\mathrm{~m}, 1 \mathrm{H}), 6.67-6.63(\mathrm{~m}, 2 \mathrm{H})$, $1.67(\mathrm{~s}, 6 \mathrm{H}) ;{ }^{13} \mathrm{C}$ NMR $\left(68 \mathrm{MHz}, \mathrm{CDCl}_{3}\right) \delta=155.5,145.7,131.4,128.7,127.1,121.5,120.9$, 120.2, 79.6, 29.4; HRMS (EI positive) Calcd for $\mathrm{C}_{15} \mathrm{H}_{15}{ }^{79} \mathrm{BrO}$ : $[\mathrm{M}+\mathrm{H}]^{+}$290.0306. Found: $\mathrm{m} / \mathrm{z}$ 290.0300 .

1-Methylcyclohexyl phenyl ether (2f). Colorless oil; IR (ATR, $\mathrm{cm}^{-1}$ ) 2930, 2858, 1592, 1491, 1221, 1154, 694; ${ }^{1} \mathrm{H}$ NMR $\left(270 \mathrm{MHz}, \mathrm{CDCl}_{3}\right) \delta=7.27-7.21(\mathrm{~m}, 2 \mathrm{H}), 7.06-6.98(\mathrm{~m}, 3 \mathrm{H})$, $1.92-1.71(\mathrm{~m}, 4 \mathrm{H}), 1.53-1.34(\mathrm{~m}, 6 \mathrm{H}), 1.25(\mathrm{~s}, 3 \mathrm{H}) ;{ }^{13} \mathrm{C} \mathrm{NMR}\left(68 \mathrm{MHz}, \mathrm{CDCl}_{3}\right) \delta=155.3$, 128.7, 123.7, 122.7, 79.6, 37.7, 26.2, 25.8, 22.7; HRMS (EI positive) Calcd for $\mathrm{C}_{13} \mathrm{H}_{18} \mathrm{O}$ : $[\mathrm{M}+\mathrm{H}]^{+}$190.1358. Found: $\mathrm{m} / \mathrm{z} 190.1359$.

1-Adamantyl phenyl ether (2g). ${ }^{26}$ White solid; IR (ATR, $\mathrm{cm}^{-1}$ ) 2906, 2854, 1486, 1213, 1055, 922, 904, 782, 700; ${ }^{1} \mathrm{H}$ NMR $\left(270 \mathrm{MHz}, \mathrm{CDCl}_{3}\right) \delta=7.28-7.22(\mathrm{~m}, 2 \mathrm{H}), 7.11-7.05(\mathrm{~m}, 1 \mathrm{H})$, 7.00-6.97 (m, 2H), 2.17 (bs, 3H), 1.87 (bs, 6H), 1.61 (bs, 6H); ${ }^{13} \mathrm{C} \mathrm{NMR}\left(68 \mathrm{MHz}, \mathrm{CDCl}_{3}\right) \delta=$ 154.0, 128.5, 124.9, 123.5, 77.6, 42.9, 36.2, 31.0; HRMS (EI positive) Calcd for $\mathrm{C}_{16} \mathrm{H}_{20} \mathrm{O}$ : $[\mathrm{M}+\mathrm{H}]^{+} 228.1514$. Found: $m / z 228.1522$.

1-Methyl-3-phenylpropyl phenyl ether (2h). ${ }^{27}$ Colorless oil; IR (ATR, $\mathrm{cm}^{-1}$ ) 2932, 1597, 1587, 1238, 748,692; ${ }^{1} \mathrm{H}$ NMR $\left(270 \mathrm{MHz}, \mathrm{CDCl}_{3}\right) \delta=7.29-7.15(\mathrm{~m}, 7 \mathrm{H}), 6.94-6.84(\mathrm{~m}, 3 \mathrm{H})$, 4.41-4.30 (m, 1H), 2.86-2.66 (m, 2H), 2.14-2.01 (m, 1H), 1.94-1.81 (m, 1H), $1.32(\mathrm{~d}, J=6.2$ $\mathrm{Hz}, 3 \mathrm{H}) ;{ }^{13} \mathrm{C} \mathrm{NMR}\left(68 \mathrm{MHz}, \mathrm{CDCl}_{3}\right) \delta=158.0,141.7,129.3,128.4,128.3,125.7,120.5,115.9$, $72.8,38.3,31.9,19.8$.

Cyclohexyl phenyl ether (2i). ${ }^{7}$ Colorless oil; IR (ATR, $\mathrm{cm}^{-1}$ ) 2933, 2857, 1598, 1587, 1492, 1234, 1048, 963, 750, 690; ${ }^{1} \mathrm{H}$ NMR $\left(270 \mathrm{MHz}, \mathrm{CDCl}_{3}\right) \delta=7.28-7.22(\mathrm{~m}, 2 \mathrm{H}), 6.92-6.87(\mathrm{~m}$, $3 \mathrm{H}), 4.27-4.18(\mathrm{~m}, 1 \mathrm{H}), 2.00-1.75(\mathrm{~m}, 4 \mathrm{H}), 1.58-1.26(\mathrm{~m}, 6 \mathrm{H}) ;{ }^{13} \mathrm{C} \mathrm{NMR}\left(68 \mathrm{MHz}, \mathrm{CDCl}_{3}\right) \delta=$ $157.7,129.3,120.4,116.0,75.4,32.0,25.7,23.9$. 
(1S, 2R, 5S)-2-Isopropyl-5-methylcyclohexyl phenyl ether (2j). ${ }^{28}$ Colorless oil; IR (ATR, $\left.\mathrm{cm}^{-1}\right) 2954,2924,2869,1597,1587,1492,1240,1013,750,690 ;{ }^{1} \mathrm{H} \mathrm{NMR}\left(270 \mathrm{MHz}, \mathrm{CDCl}_{3}\right) \delta$ $=7.30-7.24(\mathrm{~m}, 2 \mathrm{H}), 6.93-6.88(\mathrm{~m}, 3 \mathrm{H}), 4.07-3.98(\mathrm{~m}, 1 \mathrm{H}), 2.28-2.12(\mathrm{~m}, 2 \mathrm{H}), 1.76-1.68(\mathrm{~m}$, $2 \mathrm{H}), 1.56-1.38(\mathrm{~m}, 2 \mathrm{H}), 1.13-0.90(\mathrm{~m}, 9 \mathrm{H}), 0.77(\mathrm{~d}, J=6.2 \mathrm{~Hz}, 3 \mathrm{H}) ;{ }^{13} \mathrm{C} \mathrm{NMR}(68 \mathrm{MHz}$, $\left.\mathrm{CDCl}_{3}\right) \delta=158.3,129.4,120.3,115.8,77.5,48.2,40.5,34.7,31.5,26.2,23.9,22.2,20.9,16.7$; HRMS (EI positive) Calcd for $\mathrm{C}_{16} \mathrm{H}_{24} \mathrm{O}:[\mathrm{M}+\mathrm{H}]^{+}$232.1827. Found: $m / z$ 232.1825.

Phenyl 3-phenylpropyl ether (2k). ${ }^{7}$ Colorless oil; IR (ATR, $\mathrm{cm}^{-1}$ ) 2942, 1599, 1587, 1495 , 1470, 1242, 1037, 747, 691; ${ }^{1} \mathrm{H}$ NMR $\left(270 \mathrm{MHz}, \mathrm{CDCl}_{3}\right) \delta=7.32-7.16(\mathrm{~m}, 7 \mathrm{H}), 6.96-6.87(\mathrm{~m}$, $3 \mathrm{H}), 3.96(\mathrm{t}, J=6.5 \mathrm{~Hz}, 2 \mathrm{H}), 2.81(\mathrm{t}, J=7.3 \mathrm{~Hz}, 2 \mathrm{H}), 2.16-2.05(\mathrm{~m}, 2 \mathrm{H}) ;{ }^{13} \mathrm{C} \mathrm{NMR}(68 \mathrm{MHz}$, $\left.\mathrm{CDCl}_{3}\right) \delta=158.9,141.4,129.3,128.4,128.3,125.8,120.5,114.5,66.8,32.2,30.9$.

\section{Acknowledgements}

This study was supported in part by the Grant of the 21st Century COE Program from Ministry of Education, Culture, Sports, Science and Technology (MEXT), Japan. We thank Dr. Hirokazu Ohsawa and Dr. Tatsuji Nakamura, Analytical group in Banyu pharmaceutical company, for high resolution mass spectrometry analysis.

\section{References}

1. Ulmann, F. Ber. 1904, 37, 853.

2. (a) Ley, S. V.; Thomas, A. W. Angew. Chem., Int. Ed. 2003, 42, 5400. (b) Lindley, J. Tetrahedron 1984, 40, 1433. (c) Finet, J.-P.; Fedorov, A. Y.; Combs, S.; Boyer, G. Curr. Org. Chem. 2002, 6, 597.

3. Wolter, M.; Nordmann, G.; Job, G. E.; Buchwald, S. L. Org. Lett. 2002, 4, 973.

4. Hartwig, J. F. Angew. Chem., Int. Ed. 1998, 37, 2046.

5. Muci, A. R.; Buchwald, S. L. Topics in Current Chemistry 2002, 209, 133.

6. (a) Vorogushn, A. V.; Huang, X. A.; Buchwald, S. L. J. Am. Chem. Soc. 2005, 127, 8146. (b) Kataoka, N.; Shelby, Q.; Stambuli, J. P.; Hartwig, J. F. J. Org. Chem. 2002, 67, 5553.

7. Quach, T. D.; Batey, R. A. Org. Lett. 2003, 5, 1381.

8. (a) Chan, D. M. T.; Monaco, K. L.; Wang, R.-P.; Winters, M. P. Tetrahedron Lett. 1998, 39, 2933. (b) Evans, D. A.; Katz, J. L.; West, T. R. Tetrahedron Lett. 1998, 39, 2937.

9. (a) Finet, J.-P. Chem. Rev. 1989, 89, 1487. (b) Elliott, G. I.; Konopelski, J. P.; Tetrahedron 2001, 57, 5683.

10. Barton, D. H. R.; Finet, J. -P.; Motherwell, W. B.; Pichon, C. J. Chem. Soc., Perkin. Trans. 1 1987, 251.

11. Fedorov, A. Y.; Finet, J.-P. J. Chem. Soc., Perkin Trans. 1 2000, 3775; Fedorov, A.; Combes, S.; Finet, J.-P. Tetrahedron 1999, 55, 1341; Combes, S.; Finet, J.-P. Tetrahedron 1999, 55, 
3377.

12. (a) Dodonov, V. A.; Gushchin, A. V.; Brilkina, T. G. Zh. Obsch. Khim. 1984, 54, 2157. (b) Dodonov, V. A.; Gushchin, A. V.; Brilkina, T. G.; Muratova, L. V. Zh. Obsch. Khim. 1986, $56,2714$.

13. (a) David, S.; Thieffry, A. Tetrahedron Lett. 1981, 22, 5063. (b) Barton, D. H. R.; Finet, J.P.; Pichon, C. J. Chem. Soc., Chem. Commun. 1986, 65. (c) Coles, S. J.; Costello, J. F.; Hursthouse, M. B.; Smith, S. J. Organomet. Chem. 2002, 662, 98.

14. Brands, K. M. J.; Dolling, U.-H.; Jobson, R. B.; Marchesini, G.; Reamer, R. A.; Williams, J. M. J. Org. Chem. 1998, 63, 6721.

15. (a) Ikegai, K.; Fukumoto, K.; Mukaiyama, T. Chem. Lett. 2006, 35, 612. (b) Mukaiyama, T.; Sakurai, N. Ikegai, K. Chem. Lett. 2006, 35, 1140.

16. Arnauld, T.; Barton, D. H. R.; Doris, E. Tetrahedron 1997, 53, 4137.

17. Barton, D. H. R.; Bhatnagar, N. Y.; Blazejewski, J.-C.; Charpiot, B.; Finet, J.-P.; Lester, D. J.; Motherwell, W. B.; Papoula, M. T. B.; Stanforth, S. P. J. Chem. Soc., Perkin Trans. 1 1985, 2657.

18. Rahman, A. F. M. M.; Murafuji, T.; Ishibashi, M.; Miyoshi, Y.; Sugihara, Y.; J. Organomet. Chem. 2004, 689, 3395.

19. Barton, D. H. R.; Charpiot, B.; Dau, E. T. H.; Motherwell, W. B.; Pascard, C.; Pichon, C. Helv, Chim. Acta, 1984, 67, 586.

20. Matano, Y.; Nomura, H. Synthesis 2002, 631.

21. Ooi, T.; Goto, R.; Maruoka, K. J. Am. Chem. Soc. 2003, 125, 10494.

22. Wittig, G.; Clauss, K. Liebigs Ann. Chem. 1952, 578, 136.

23. Suzuki, H.; Ogawa, T.; Komatsu, N.; Matano, Y.; Murafuji, T.; Ikegami, T. Organobismuth Chemistry, Elsevier: Amsterdam, 2001.

24. Lykakis, I. N.; Orfanopoulos, M. Tetrahedron Lett. 2004, 45, 7645.

25. Spivey, A. M. J. Chem. Soc. 1953, 1647.

26. Udo, K. Chem. Ber. 1973, 106, 3095.

27. Yang, C.-G.; He, C. J. Am. Chem. Soc. 2005, 127, 6966.

28. Bird, C. W.; Lewis, A. Tetrahedron Lett. 1989, 30, 6227. 